\author{
KonRAD WOŁOWSKI, MARIA JANICKA, LUCYNA ŚliWA \\ Instytut Botaniki im. W. Szafera PAN \\ Lubicz 46, 31-512 Kraków \\ E-mail:k.wolowski@botany.pl
}

\title{
KARTOTEKA STANOWISK GLONÓW POLSKI W ZBIORACH NAUKOWYCH INSTYTUTU BOTANIKI IM. W. SZAFERA POLSKIEJ AKADEMII NAUK
}

\section{WSTEP}

Zbiory naukowe gromadzone sa $\mathrm{w}$ Instytucie Botaniki im. W. Szafera PAN od prawie 70. lat i stanowia jedna $z$ najważniejszych w skali krajowej oraz znaczaca w skali międzynarodowej kolekcję zbiorów zielnikowych. Zbiory te sa nie tylko dokumentem historycznym, ale także podstawowym punktem odniesienia dla wszystkich badan z zakresu fitotaksonomii, ewolucjonizmu i fitogeografii, prowadzonych aktualnie w krajowych ośrodkach botanicznych. Sa również bazą dla wielostronnej współpracy międzynarodowej. Obecnie kolekcje zielnikowe Instytutu, których łączna liczba numerów inwentarzowych wynosi blisko 1500 000, obejmuja nie tylko wszystkie grupy współczesnych roślin i grzybów (w tym jedna $z$ trzech największych na świecie ikonotek glonów), ale także kolekcje flor kopalnych i zbiór okazów referencyjnych dla badań paleobiologicznych. W 2020 r. po przejściu procedury konkursowej Ministerstwa Nauki i Szkolnictwa Wyższego, zbiory naukowe Instytutu Botaniki zostały wpisane na POLSKA MAPE INFRASTRUKTURY BADAWCZEJ (2020) pod nazwa Narodowa Kolekcja Bioróżnorodności Organizmów Współczesnych i Kopalnych IB PAN (NKB IB PAN). Oznacza to, że zostały zaliczone do grupy wartościowych przedsięwzięć naukowych o strategicznym znaczeniu w skali kraju.

Ważnym elementem tej kolekcji sa zbiory glonów. Zbiory glonów (KRAM A) stanowi obecnie około 5000 okazów zielnikowych suchych. W zbiorach glonów znajduja się też wydzielone, cenne kolekcje eksykatów Phycotheca Polonica autorstwa M. Raciborskiego, Die Algen Europa's L. Rabenhorsta i Algae Aque Dulcis Exiccatae V. Wittrocka i O. Nordstedta. Odrębną część stanowi ponadto zbiór okazów glonów utrwalonych w płynach konserwujących (np. historyczne zbiory porównawcze glonów wodnych) lub przechowywanych w postaci kultur żywych. Do tych ostatnich należa przede wszystkim aerofityczne glony obszarów zurbanizowanych i hałd przemysłowych oraz, kolekcja gatunków rodzaju Pediastrum z jezior i stawów Polski. Unikatowym elementem zbioru glonów w skali fykologii światowej jest ikonoteka, która powstała w latach 60. ubiegłego stulecia na wzór Fritsch Collection of Freshwater Algal Illustrations, w Windermere w Wielkiej Brytanii. Ikonoteka glonów IB PAN jest obecnie jedyna $w$ Polsce $i$ jedna $z$ trzech największych na świecie. Stanowi cenna formę dokumentacji materiałów porównawczych i zawiera 415510 rycin, w tym 11150 dla nowo opisanych taksonów (w XX w. i później), wraz $z$ indeksem alfabetycznym nazw taksonów i bibliografią licząca 7350 pozycji. Ważna składowa zbiorów jest także kartoteka stanowisk glonów Polski licząca 28000 kart.

W ramach realizacji projektu IMBIO do digitalizacji przeznaczona została część zbiorów glonów. Sa to: kartoteka stanowisk glonów Polski, katalog nazw glonów odnotowywanych w kraju i bibliografia przedmiotu 
do 2000 r., stanowiace fykologiczna dokumentację naukową. Tak więc, w niniejszym opracowaniu prezentujemy informacje o historycznych i współczesnych danych o glonach odnotowanych $\mathrm{w}$ Polsce, metodach ich gromadzenia oraz o ich znaczeniu i wplywie na postęp badań fykologicznych w kraju i na świecie.

\section{GLONY - DEFINICJA I ZNACZENIE}

Glony (algi) sa wyjatkowa grupa organizmów, nie tylko $z$ punktu widzenia ekologicznego, fizjologicznego, ale i filogenetycznego, bowiem znajduja się wśród nich przodkowie wszystkich roślin lądowych. Organizmy te występuja na całej kuli ziemskiej, w wodach zarówno słonych, jak i słodkich, zajmujacych około $2 / 3$ powierzchni Ziemi. Stanowily od samego poczatku podstawowy i najważniejszy element powstania życia na Ziemi, zmieniajac atmosferę planety i rozpoczynając ewolucję organizmów eukariotycznych. Odegrały istotna rolę w kredzie jako główne źródło obecnych złóż ropy i gazu. Wciąż dostarczaja około połowy tlenu na naszej planecie, tym samym zabezpieczaja nasze życie. Bezpośrednio lub pośrednio stanowia źródło pożywienia, będąc ważnym ogniwem $w$ łańcuchu pokarmowym. Fakt, że algi sa również potencjalnym źródłem odnawialnych biopaliw sprawia, że według CHAPMANA (2010): „(...) te najważniejsze w życiu świata 'rośliny' sa jeszcze ważniejsze."

Glony to popularna nazwa wielu rozmaitych fotosyntetyzujacych grup systematycznych organizmów, $\mathrm{w}$ istocie znacznie różniących się między soba (ultrastruktura komórek, w tym budowa jąra, tylakoidów, produkowanymi barwnikami i materiałami zapasowymi czy rodzajem wytwarzanych struktur zewnętrznych np. pancerzyków). Sa wśród nich prokariotyczne (bezjądrowe) sinice i prochlorofity oraz eukariotyczne (posiadające jądro komórkowe) krasnorosty, glaukofity, zielenice, ramienice, chlorarachnofity, haptofity, brunatnice, chryzofity, dinofity i eugleniny (BROODIE i LEWIS 2007). Olbrzymie zróżnicowanie genetyczne i morfologiczne tych organizmów jest powodem prowadzenia badań nad konstruowaniem ich drzewa filogenetycznego, w których efekcie całe grupy glonów klasyfikowane sa odmiennie niż dotychczas. Dlatego terminu glony należy używać wyłącznie w znaczeniu ekologicznym, gdy mowa jest o zbiorowiskach $\mathrm{i}$ siedliskach, np. zbiornikach wodnych czy matach biologicznych, w obrębie których spotyka się przedstawicieli różnych grup systematycznych glonów.
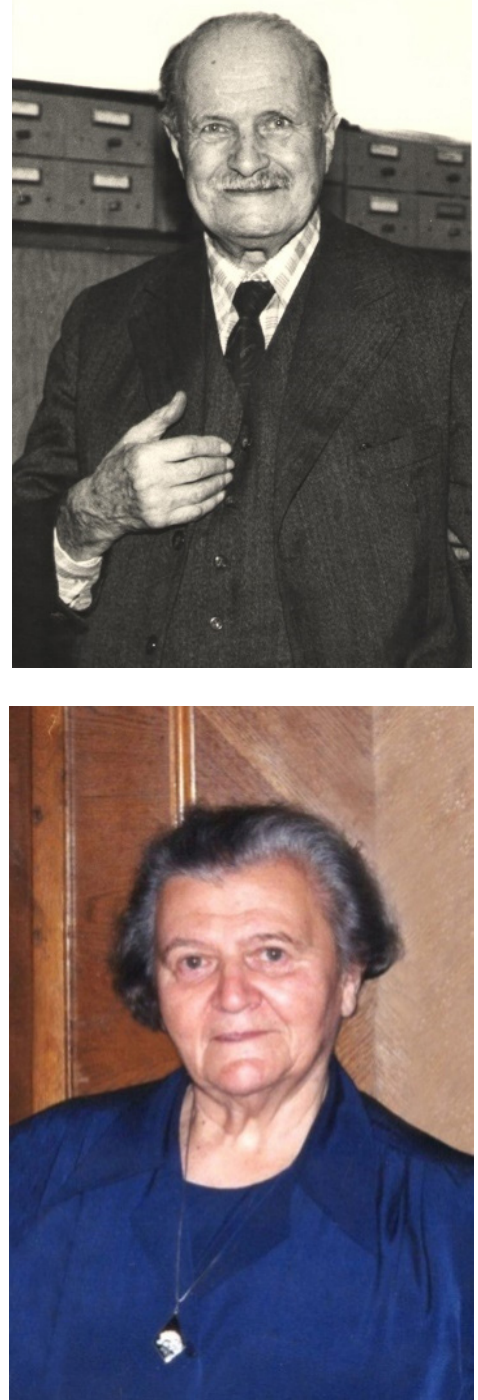

Ryc. 1. Organizatorzy zbiorów fykologicznej dokumentacji naukowej w Zakładzie Fykologii Instytutu Botaniki im. W. Szafera PAN: prof. Karol Starmach, prof. Jadwiga Siemińska.

\section{FYKOLOGICZNA DOKUMENTACJA NAUKOWA}

Monitorowanie prawidłowości funkcjonowania ekosystemów wodnych narzuca konieczność poznania ich mieszkańców, m.n. glonów, a rozpoznanie składu ich zbiorowisk jest podstawa do oceny charakteru ekologicznego różnych zbiorników. Wage tego zagadnienia dostrzegał i doskonale rozumiał znany hydrobiolog i algolog, prof. Karol Starmach. Dlatego zaraz po II wojnie światowej rozpoczał realizacje jednego z kluczowych powojennych projektów - założenie ogólnopolskiego centrum badań fykologicznych (algologicznych), majacego za zadanie kształcenie i wspomaganie badaczy zainteresowanych różnymi grupami glonów. 

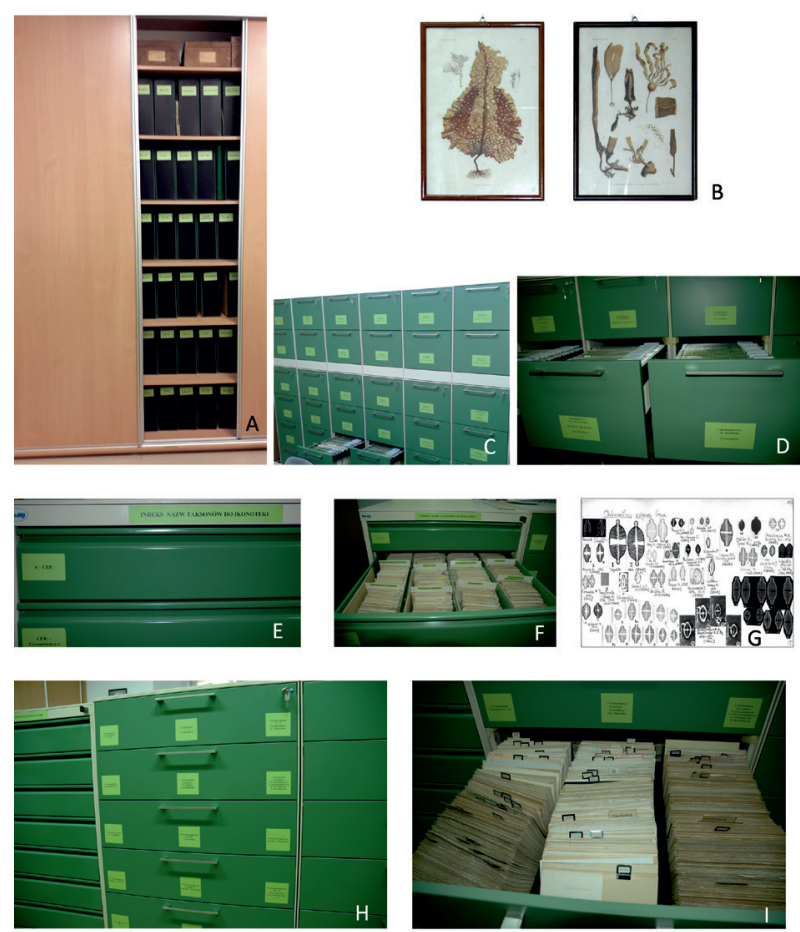

Ryc. 2. Organizacja zbiorów dokumentacji fykologicznej w IB PAN. A. Zbiór bibliograficzny; B. Ryciny autorstwa prof. Józefa Rostafińskiego; C, D. Fragment zbiorów ikonoteki; E, F. Katalog nazw taksonów glonów; G. karta ikonoteczna; H. Kartoteka stanowisk glonów podawanych z Polski; I. Układ kart.

W tym ambitnym zamierzeniu uczestniczyła od samego poczatku uczennica profesora, prof. Jadwiga Siemińska-Słupska (Ryc. 1), badaczka okrzemek współczesnych i kopalnych oraz długoletnia kierownik, powstałego z czasem, Zakładu Fykologii IB PAN.

Projekt pierwotnie realizowany był $\mathrm{w}$ ramach Działu Algologicznego powołanego w 1954 r. przy pracowni Flory Polski, przemianowanego w 1956 r. na Pracownię Algologii (wówczas w Dziale Niższych Roślin Zarodnikowych). Duże zainteresowanie fykologia i znaczacy przyrost kadry spowodował, że już w 1960 r. Pracownię przekształcono w Zakład Algologii, który w 2000 r. przemianowano na Zakład Fykologii. Do zadań Zakładu należało prowadzenie badań nad flora glonów naszego kraju, gromadzenie wszelkich danych o ich wysteppowaniu (majacych umożliwić nowoczesne opracowywanie wielu grup systematycznych) i wydawanie kolejnych opracowań (tomów) flory glonów Polski. Zadanie to nigdy nie straciło na aktualności i nadal jest realizowane, również $w$ innych ośrodkach naukowych Polski.

Dla ułatwienia i przyspieszenia realizacji poznania flory glonów Polski, obok gromadzenia zbiorów zielnikowych, podjęto aktyw-

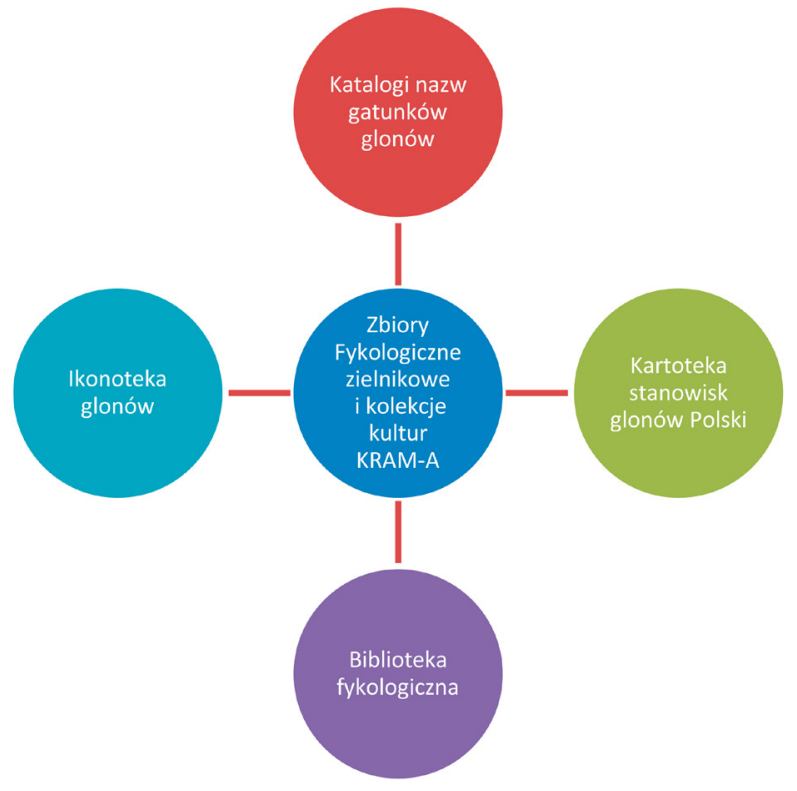

Ryc. 3. Elementy składowe zbiorów naukowych zgromadzonych w Zakładzie Fykologii Instytutu Botaniki im. W. Szafera PAN (obecnie w NKB IB PAN).

ność w zakresie kompleksowego dokumentowania fykologicznych danych naukowych. Utworzono uzupełniające się wzajemnie zbiory: kartotekę stanowisk glonów Polski, bibliotekę, ikonotekę glonów i katalog nazw taksonów glonów podawanych $z$ Polski i swiata (Ryc. 2, 3). Zgromadzona dokumentacja naukowa stanowi obecnie w całości zasoby Narodowej Kolekcji Bioróżnorodności Organizmów Współczesnych i Kopalnych IB PAN.

\section{KARTOTEKA STANOWISK GLONÓW PODAWANYCH Z POLSKI}

Historia kartoteki sięga początków Instytutu Botaniki Polskiej Akademii Nauk. Warto jednakże dodać, że sama idea zbierania danych o występowaniu glonów jest jeszcze starsza, bowiem już przed wojna prof. Karol Starmach gromadził informacje o stanowiskach krasnorostów, zielenic i cyjanobakterii w potokach górskich. Natomiast zintensyfikowanie prac nad gromadzeniem tych danych łączy się nieodłacznie z utworzeniem Pracowni Algologii w 1956 r. Działania w ramach tworzenia kartoteki (Ryc. 4) polegały na wyszukiwaniu opracowań naukowych i popularnonaukowych (książek, artykułów, broszur, odbitek) o glonach $z$ terenu Polski i gromadzeniu w sposób uporządkowany ich oryginałów lub kopii. W ten sposób w ramach Pracowni (jak wspomnian,o przekształconej później w Zakład Fykologii) powstał zbiór 

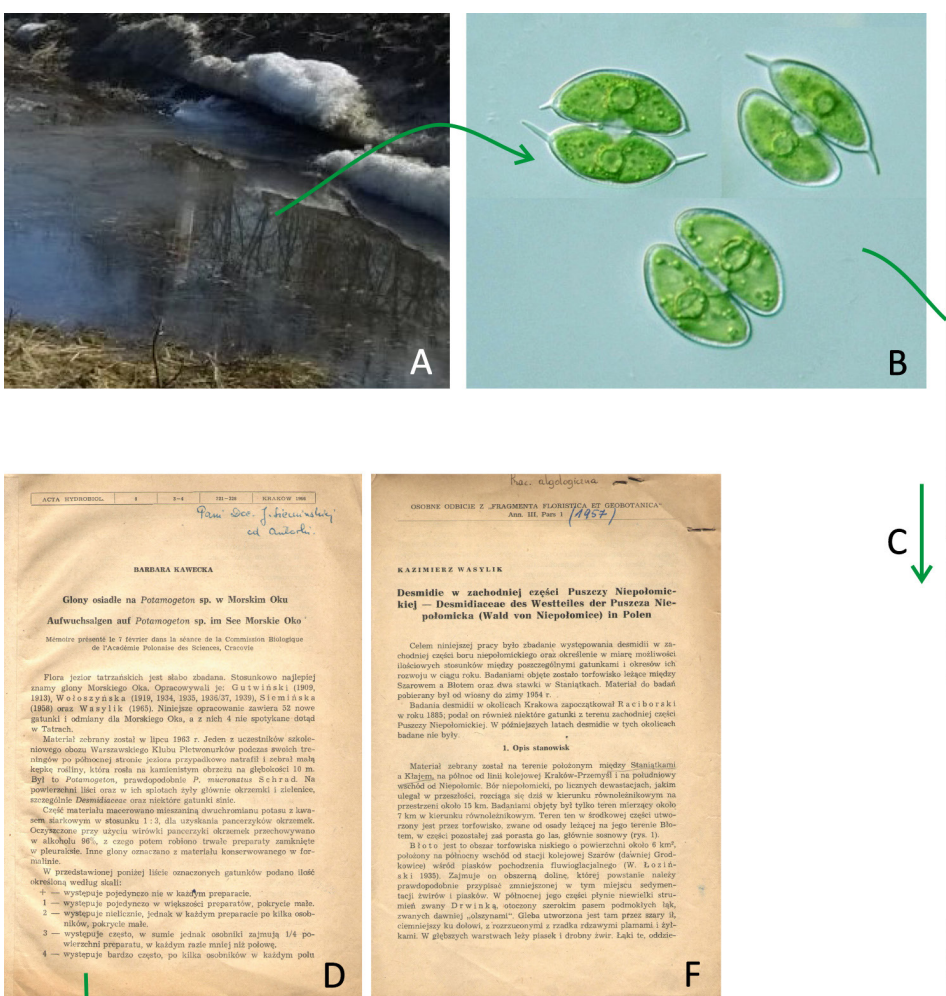

D

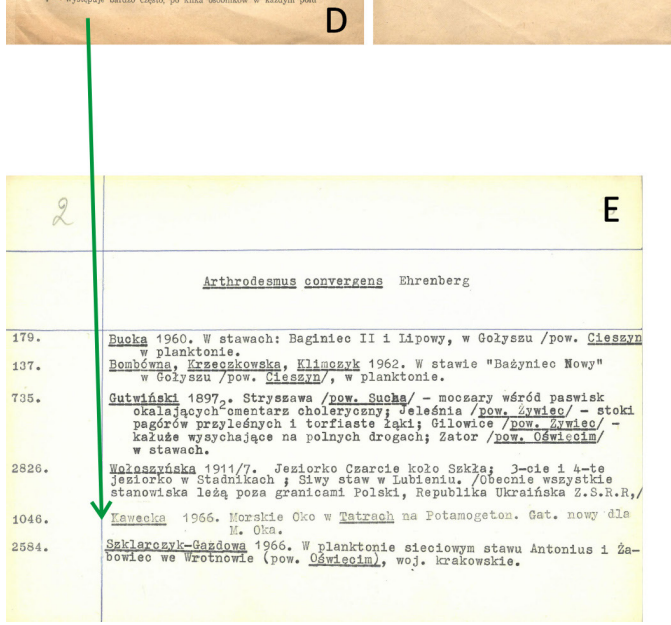

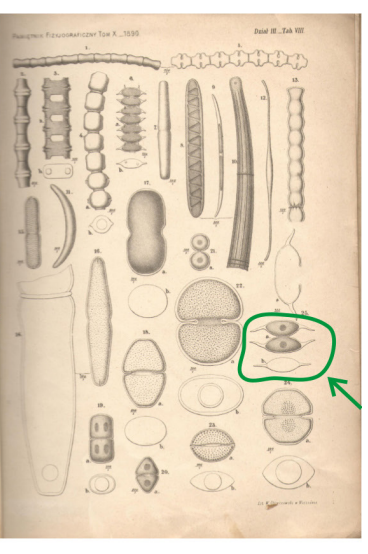

C

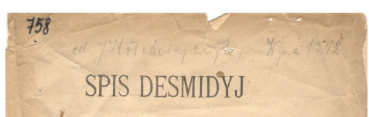

SPIS DESMIDYJ

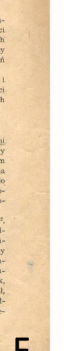

F
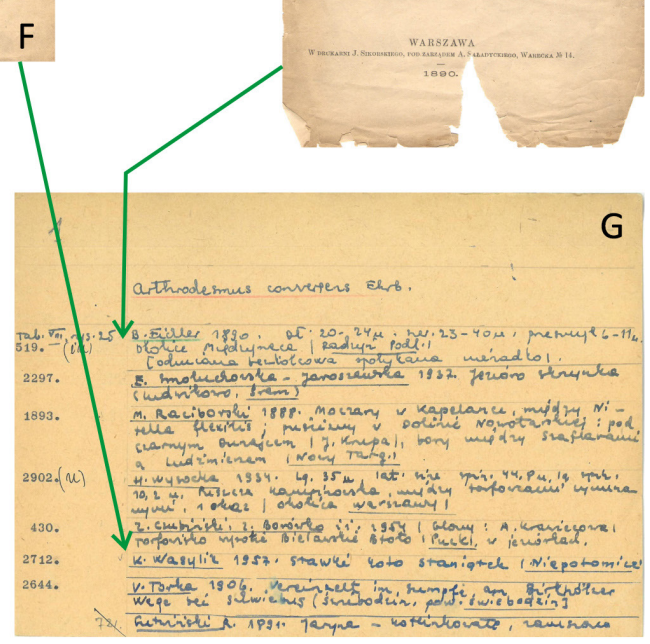

Ryc. 4. Etapy opracowywania kart stanowisk (od lewej): A. Pobór próby; B. Identyfikacja gatunku; C, D, F. Dane bibliograficzne: C. EichleR (1890); D. KAWECKA (1966); F. WASYLIK (1957); E, G. Zapis danych na kartę dla gatunku - Arthrodesmus convergens Ehrenberg ex Ralfs = Staurodesmus convergens (Ehrenberg ex Ralfs) S. Lillieroth (COESEL i MEESTERS 2007) (Arthrodesmus/convergens/convergens_01b. html).

opracowań o glonach Polski (biblioteka fykologiczna). Zgromadzone publikacje stanowia główne źródło informacji, na podstawie których rozpisywano karty dla poszczególnych taksonów (gatunków, podgatunków, odmian i form, a czasem tylko dla rodzajów). W kartotece znajduja się dane o występowaniu na terenie Polski glonów ze wszystkich grup systematycznych, zarówno słodkowodnych, jak i morskich, współcześnie żyjących i kopalnych. W kartotece znalazły się również karty stanowisk dla bakterii i sinic (cyjanobakterii) ze względu na ich historyczna przynależność do świata roślin. Mając na uwadze tradycyjny aspekt istniejacej kartoteki stanowisk, zacho- waliśmy układ kart oparty w dużej mierze na założeniach systemu Paschera (Ryc. 5).

Dane do kartoteki stanowisk uzupełniane były przez 26 lat (od 1954 do1980 r.). Kartotekę według instrukcji (Ryc. 6) sporządzali i opracowywali na poczatku pracownicy naukowi Zakładu. W pierwszych latach byli to: Bolesława Kawecka-Starmachowa (sinice), następnie Jadwiga Siemińska (okrzemki) i Teresa Mrozińska (uwikła) oraz Kazimierz Wasylik (desmidie). Dalej od 1969 r. wpisywaniem danych na karty zajmowały się głównie: Anna Hrebendowa, potem Krystyna Hojda, a następnie Jadwiga Grzbielowa. Wspomagały je w różnym czasie: Anna Derlaga, Zofia Dyr- 


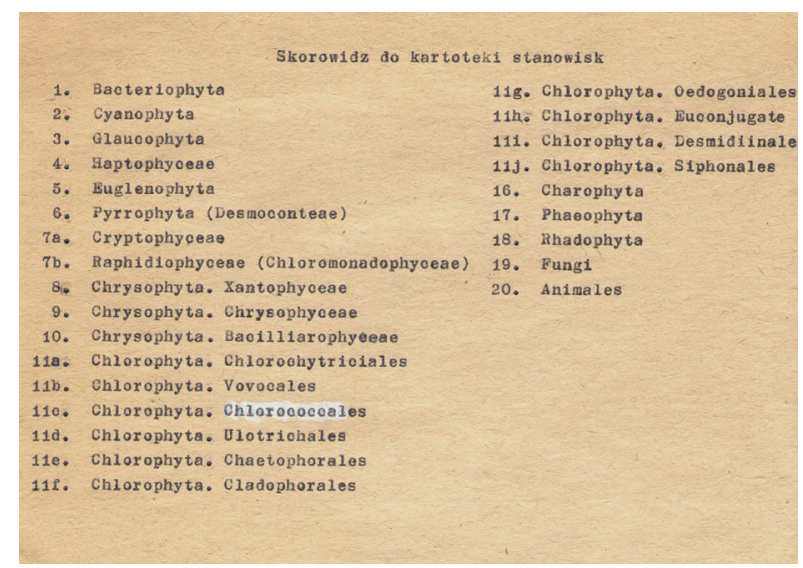

Ryc. 5. Oryginalna karta ze skorowidzem do kartoteki stanowisk.

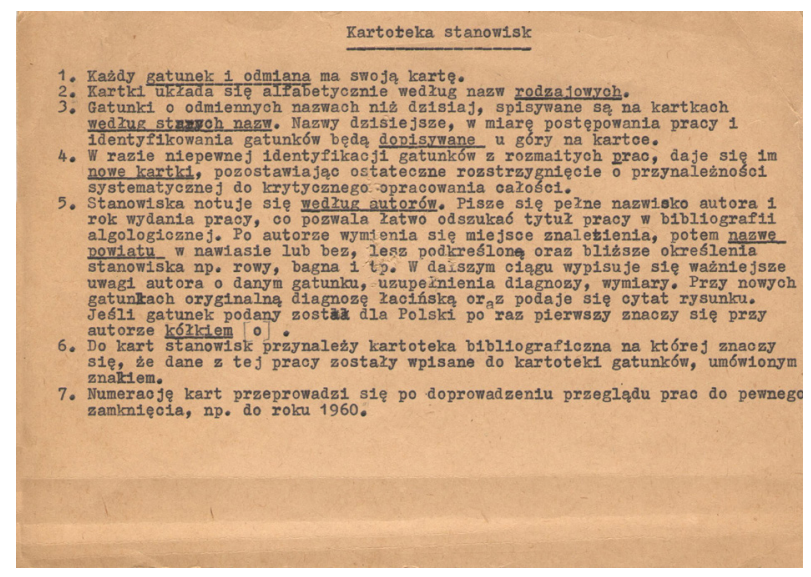

Ryc. 6. Oryginalna karta $z$ objaśnieniem układu zapisu na kartach stanowisk.

ga i Jolanta Pajak. W ostatnim czasie wpisywaniem stanowisk na karty zajmowała się głównie Lucyna Żak-El Shahed. Najstarsze karty zostały wypisane pismem odręcznym, nowsze - pismem maszynowym (Ryc. 4G, 7). Kartoteka liczy obecnie około 28000 kart, w tym około 25000 kart stanowisk przedstawicieli różnych grup glonów, 1681 kart stanowisk sinic (cyjanobakterii) i 1422 karty stanowisk bakterii. To, jak na owe czasy nowoczesne podejście do zagadnienia gromadzenia danych, znacznie skracało czas potrzebny na poszukiwanie informacji o gatunkach i stanowiskach alg odnotowywanych na terenie Polski. Pozwalało też dotrzeć do źródłowych informacji zawartych w zgromadzonych opracowaniach. Również współcześnie kartoteka pozwala na szybkie poruszanie się w bogatym zbiorze danych o miejscu występowania określonych taksonów glonów, szczególnie publikowanych w mniej znanych pracach lub w mało dostępnych opracowaniach historycznych (sięgajacych często XIX w.).

Nie ulega wątpliwości, że najistotniejszym sposobem wykorzystania kart stanowisk było

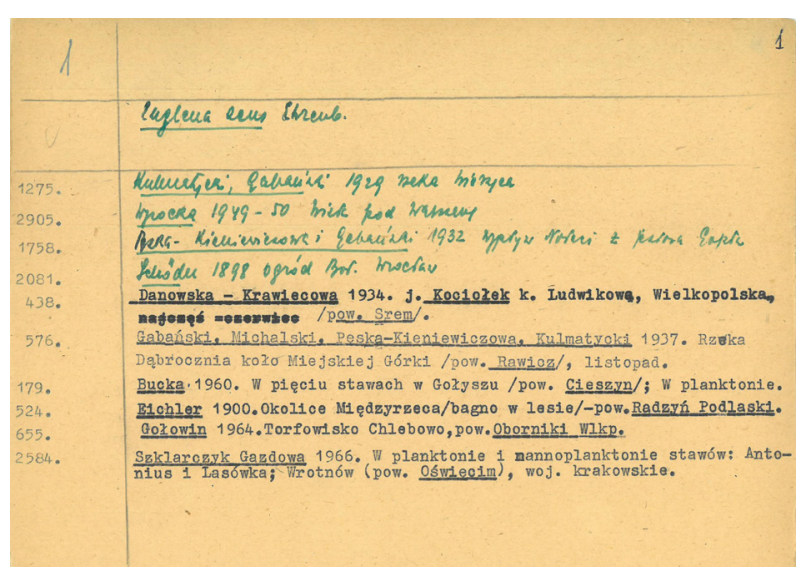

Ryc. 7. Przykład jednej $z$ najstarszych kart dla Euglena acus (O.F. Müller) Ehrenberg = Lepocinclis acus (Müller) Marin et Melkonian).

opracowanie Index of latin names of Blue-Green algae taxa (Cyanophyta) - Noted in Poland up to the year 1980 (SIEMIŃSKA 1995), a później Catalogue of Polish prokaryotic and eukaryotic algae - Katalog glonów prokariotycznych $i$ eukariotycznych Polski autorstwa SIEMIŃSKIEJ i WOŁOWSKIEGO (2003), przy dużym wkładzie pracy Lucyny Żak-El Shahed (Ryc. 8). Liczby w kolumnach po lewej stronie kart sa odsyłaczami do pozycji literatury przedmiotu w kartotece bibliograficznej i kolejnych tomach bibliografii fykologicznej.
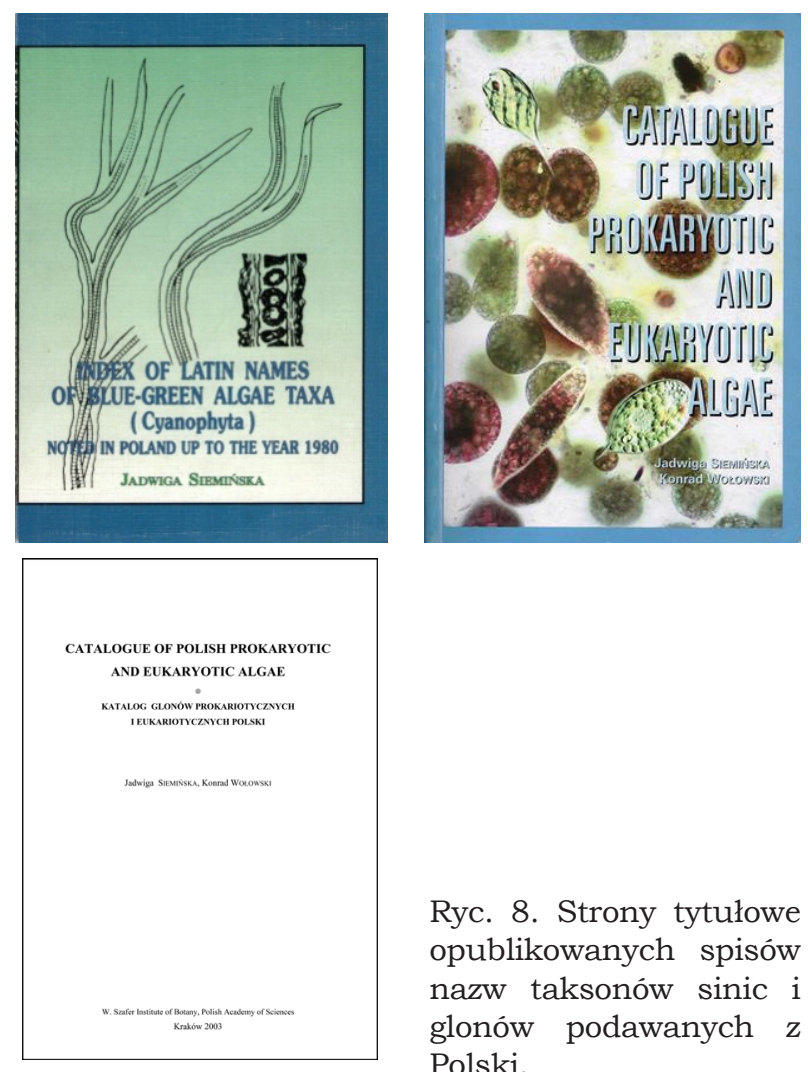

Ryc. 8. Strony tytułowe opublikowanych spisów nazw taksonów sinic i glonów podawanych $\mathrm{z}$ Polski. 
Warto zaznaczyć, że zarówno w kartotece stanowisk glonów, jak i w publikowanych materiałach stanowiących kolejne spisy (katalogi) nazw glonów podawanych z Polski (SIEMiŃSKa 1995, Siemińska i WoŁowski 2003) pozostawiono oryginalne nazwy taksonów, czyli takie pod jakimi zostały opublikowane. Obecnie sa one korygowane i aktualizowane do poziomu gatunków, zgodnie $z$ najnowsza nomenklatura algologiczna (GUIRY i GUIRY 2021, InDEX Nominum ALGARUM).

Katalog stanowisk glonów może być w dalszym ciagu uzupełniany $\mathrm{i}$ w pełni wykorzystany tylko pod warunkiem kontynuacji wydania kolejnych tomów bibliografii fykologicznej. Numery podane obok poszczególnych taksonów sa pochodna inwentaryzacji literatury fykologicznej $\mathrm{w}$ formie publikowanych bibliografii i sa zgodne $z$ numerami znajdujacymi się na kartach stanowisk.

\section{WARTOŚĆ KARTOTEKI STANOWISK GLONÓW DLA BADAN NAUKOWYCH}

Kartoteka stanowi ważny zbiór danych zawierający zróżnicowane informacje przyrodnicze o taksonach, ich rozmieszczeniu, ekologii i siedlisku wraz $z$ kompletem bibliografii. Będąc swoista baza danych, kartoteka umożliwia prowadzenie różnego typu analiz $z$ wykorzystaniem nowoczesnych metod badawczych, w tym narzędzi matematycznych (modelowanie, analizy statystyczne). W wielu przypadkach zapisy w kartotece dokumentuja stanowiska historyczne, niezwykle ważne $z$ perspektywy badań nad bioróżnorodnością, geografia i ekologia glonów (reakcją na zmianę warunków siedliskowych, plastycznością, zakresem tolerancji, przemianami ich ugrupowań). Dzięki informacjom o znanych lokalizacjach poszczególnych gatunków możliwe jest odnalezienie stanowisk i pobranie prób do badań genetycznych, ekochemicznych i innych, niezbędnych współcześnie do prowadzenia prac taksonomicznych nad krytycznymi grupami gatunków. Karty stanowia „wyciag" z publikowanych danych i sa wstępem, a zarazem wskazówka do dalszych poszukiwań; umożliwiaja też szybkie uzyskanie najważniejszych informacji. Ma to szczególne znaczenie dla badaczy zagranicznych, w przypadku których dotarcie do danych lokalnych, a nawet regionalnych jest mocno utrudnione lub niemożliwe.

\section{DOTYCHCZASOWE WYKORZYSTANIE KARTOTEKI W BADANIACH NAUKOWYCH}

Poza przygotowaniem spisów nazw taksonów podanych $z$ naszego kraju, kartoteka stanowisk glonów była wykorzystywana pod-
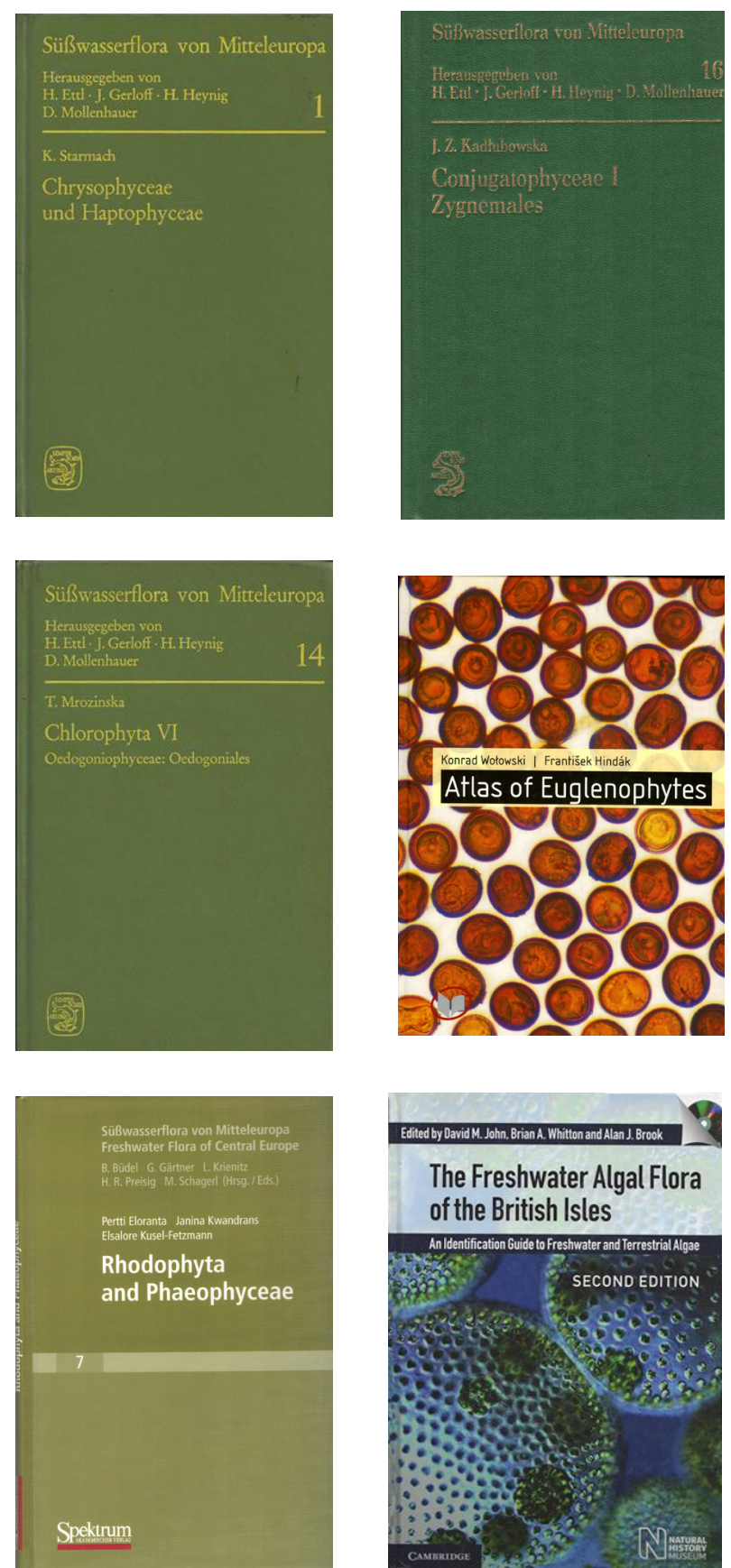

Ryc. 9. Przykładowe publikacje obcojęzyczne, do opracowania których wykorzystano między innymi dane ze zbiorów kartoteki stanowisk glonów Polski.

czas opracowywania monografii, w tym także do przygotowywania prac licencjackich, magisterskich i doktorskich jako baza poszukiwania danych źródłowych o geografii i ekologii gatunków. Zgromadzone w kartotece dane zostały niewatpliwie wykorzystane do opracowania 13 tomów Flory Stodkowodnej Polski oraz zawartych w niej kluczy do oznaczania glonów. Były to opracowania takich badaczy jak: STARMACH (1972, 1974, 1977, 1980, 1983, 1985), SIEMIŃSKA (1964), KA- 
DŁUBOWSKA (1972), MROZIŃSKA-WEBB (1969) i MROZIŃSKA (1984). Ciekawymi przykładami są także opracowania fizjograficzne różnych grup glonów, np. Oedogoniales - MROZIŃSKA (1984); Bacillariophyceae - WOJTAL (2013), Euglenophyta - WoŁOWSKI (1998), Pediastrum - LENARCZYK (2014), glony Bałtyku - Pliński i WoŁOWSKI (2008, 2012) czy popularno-naukowych, takich jak SIEMIŃSKA i współaut. (2008) oraz WoŁoWSKI i współaut. (2010). Kartoteka stanowiła również ważny zasób informacji podczas przygotowywania kolejnych tomów znanej serii Süßwasserflora von Mitteleeuropa (KADŁUBOWSKA 1984, MROZIŃSKA 1985, STARMACH 1985, ELORANTA i współaut. 2011), czy do opracowania Freshwater flora of British Isles (WoŁOWSKI 2002, 2011) i flory euglenin Słowacji i Polski (WoŁOWSKI i HINDAK 2005) (Ryc. 9).

Z zasobów kartoteki stanowisk korzystali badacze $z$ całej Polski i $z$ zagranicy. Kartoteka udostępniana była na miejscu, w Instytucie Botaniki PAN, a w ostatnich 20. latach także drogą elektroniczną. Niestety, w większości przypadków w powstałych pracach nie zamieszczono informacji o fakcie korzystaniu $z$ tego źródła danych, gdyż przez lata nie było to oficjalnie wskazane jako dobra praktyka $\mathrm{w}$ nauce.

\section{INNE ELEMENTY DOKUMENTACJI FYKOLOGICZNEJ}

Warto wspomnieć w tym miejscu dwie kolejne formy prowadzonej dokumentacji naukowej w zakresie glonów, które łączą się z kartoteka stanowisk. Pierwsza $z$ nich jest katalog bibliograficzny stanowiący ważny element źródłowy danych gromadzonych w postaci tradycyjnych fiszek bibliotecznych, a ostatnio także systematycznie prowadzonych zapisów w elektronicznej bazie literatury fykologicznej. Prowadzenie katalogu przyczyniło się w dużym stopniu do zbudowania sporego zbioru literatury fachowej (biblioteki fykologicznej) wykorzystywanej przy tworzeniu kartoteki stanowisk. Do tego zbioru właczone sa pozycje literatury ze zbiorów prywatnych profesorów: Mariana Raciborskiego, Józefa Rostafińskiego, Romana Gutwińskiego, Jadwigi Wołoszyńskiej, Karola Starmacha, Jadwigi Siemińskiej-Słupskiej, Haliny Buckiej i Teresy Mrozińskiej, mistrzów krakowskiej szkoły algologicznej. Katalog bibliograficzny flory glonów Polski stanowił podstawę do opracowywania kolejnych trzech tomów bibliografii fykologicznej Polski (SIEMIŃSKA 1990, SIEMIŃSKA i PAJĄK 1992, SIEMIŃSKA i WOŁOWSKI 2012). Ostatni tom powstał $z$ nieocenionym udziałem Lucyny Żak-El Shahed (Ryc. 10).
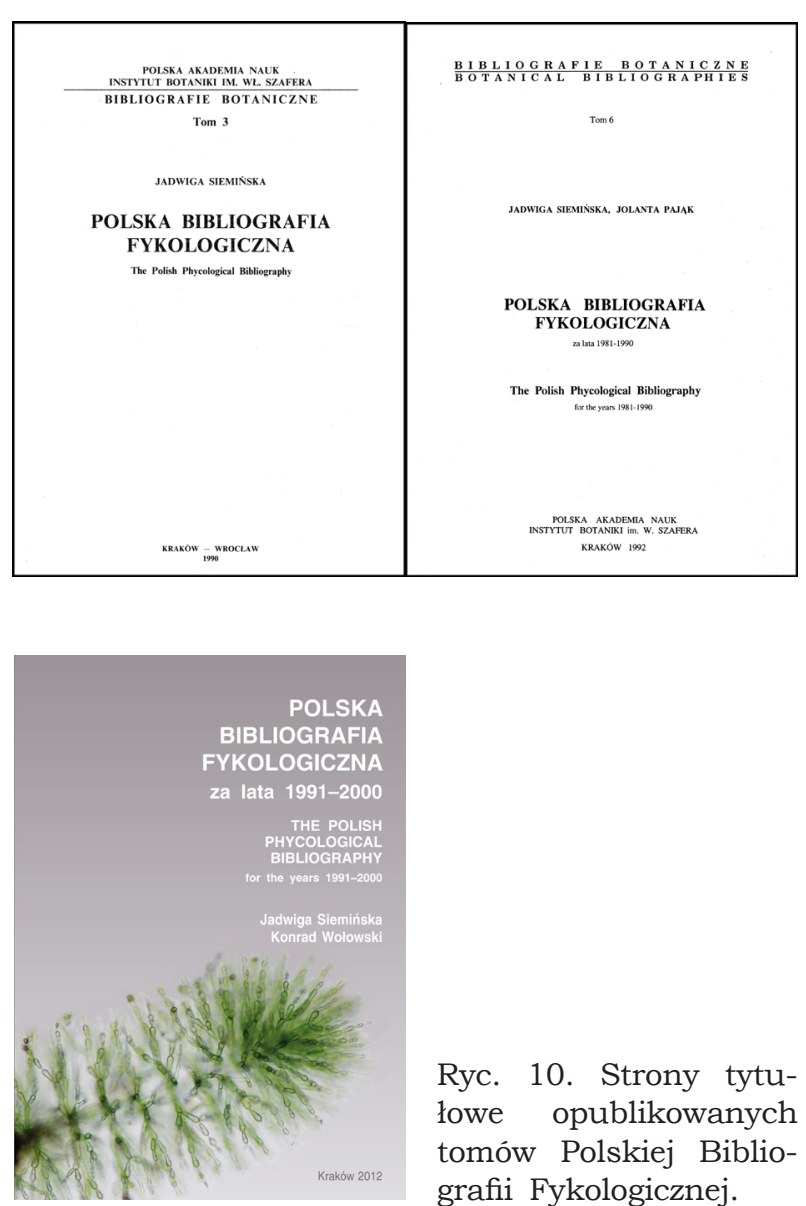

Ryc. 10. Strony tytulowe opublikowanych tomów Polskiej Bibliografii Fykologicznej.

Druga, niezwykle cenna składowa zbiorów fykologicznych w IB PAN, jest Ikonoteka glonów powstała w latach 60. ubiegłego stulecia za sprawa prof. Jadwigi Siemińskiej, na wzór Fritsch Collection of Freshwater Algal Illustrations, kompletowanej w Institute of Freshwater Ecology w Windermere w Wielkiej Brytanii. Ten unikatowy zbiór rycin glonów $z$ całego świata służy zarówno polskim, jak i zagranicznym specjalistom prowadzacym badania $z$ zakresu taksonomii i fizjografii glonów. Stanowiąc zbiór referencyjnych ilustracji (rysunków, fotografii), kolekcja ta spełnia podobna rolę jak zielniki. Szczególnie ważne przy kompletowaniu ikonoteki jest uwzględnianie na bieżąco nowo opisywanych taksonów glonów. Jedyną bowiem forma dokumentowania tych często mikroskopijnych organizmów jest ikonografia publikowana w różnych czasopismach na całym świecie. Zbiory gromadzone w postaci ikonoteki w wielu przypadkach stanowia jedyne łatwo dostępne źródło wizualnej informacji o poszczególnych taksonach. Ikonoteka zawiera obecnie około 500000 rycin, indeks alfabetyczny ilustrowanych nazw taksonów i bibliografię. Jest to jedyny tego typu zbiór w Polsce, drugi w Europie, a trzeci w świecie. 
Prace prowadzone obecnie w ramach projektu IMBIO, obejmujace digitalizacje wykazu nazw glonów wraz $z$ danymi bibliograficznymi oraz digitalizację oryginalnych kart ze stanowiskami glonów podawanych $z$ naszego kraju, pozwola na upowszechnienie zawartych w nich informacji. Tym samym przyśpiesza zaistnienie zbiorów naukowych IB PAN poprzez cytowanie w szerszej literaturze, na wzór już istniejących tego typu baz. Przyszłościowym rozwiazaniem byłoby połaczenie bazy stanowisk i bibliografii w nich ujętej ze zdigitalizowanymi wersjami źródłowych opracowań naukowych, które sa często trudne do uzyskania poza IB PAN.

Istotnym elementem procesu realizacji programów UE Polska Cyfrowa, obok programu IMBIO, był równolegle realizowany również (przez zespół fykologów IB PAN) program OZwRCIN, dzięki któremu udało się zdigitalizować $\mathrm{m}$. in. dużą część zbiorów Phycotheca Polonica autorstwa M. Raciborskiego i zbiorów autorstwa L. Rabenhorsta. W sumie zdigitalizowano dane dla 1500 okazów wraz $z$ mikroskopową dokumentacja fotograficzną.

\section{Streszczenie}

Zbiory IB PAN stanowia podstawowa w skali krajowej i znaczaca w skali międzynarodowej kolekcję zbiorów zielnikowych, których łączna liczba numerów inwentarzowych wynosi blisko 1500 000. Zbiory obejmuja nie tylko wszystkie grupy współczesnych roślin i grzybów, $\mathrm{w}$ tym jedna $\mathrm{z}$ trzech największych na świecie ikonotek glonów (415 510 kart), ale także kolekcje flor kopalnych i okazów referencyjnych dla badań paleobiologicznych. W 2020 r. zbiory Instytutu zostały wpisane na Polska Mape Infrastruktury Badawczej pod nazwa Narodowa Kolekcja Bioróżnorodności Organizmów Współczesnych i Kopalnych IB PAN (NKB IB PAN). Spośród 7 kolekcji IB PAN, część zbiorów fykologicznych przeznaczono do digitalizacji w ramach projektu IMBIO. Kolekcja fykologiczna obecnie zawiera zielnik (około 5000 zinwentaryzowanych składek), kolekcję kultur glonów, ikonotekę glonów (415 510 kart) i kartotekę stanowisk glonów podawanych z Polski, która zostanie zdigitalizowana. Kartoteka ta liczy obecnie około 28000 kart, w tym około 25000 kart stanowisk przedstawicieli różnych grup glonów oraz 1681 kart stanowisk sinic (cyjanobakterii) i 1422 karty stanowisk bakterii. Każda karta zawiera nazwę gatunkowa, miejsce zbioru i numer publikacji, w której informacja została zamieszczona (wg publikowanych bibliografii fykologicznych). Kartoteka wraz $z$ katalogiem bibliografii fykologicznej umożliwiała powstanie i opublikowanie kolejnych spisów nazw glonów podawanych z Polski. Obecnie te same zasoby posłuża do zaktualizowania tych spisów i zaproponowania $\mathrm{w}$ ramach projektu IMBIO pierwszego, w dodatku cyfrowego, wykazu glonów Polski.

\section{LITERATURA}

BROODIE J., LEWIS J., 2007. Unravelling the algae the past, present and future of algal systematics. CRC Press Taylor \& Francis Group.

POLSKA MAPA INFRASTRUKTURY BADAWCZEJ, 2020. Ministerstwo Nauki i Szkolnictwa Wyższego
CHAPMAN R. L., 2010. Algae: the world's most important "plants" - an introduction. Mitigation Adapt. Strateg. Global Change 18, 5-12.

Coesel P. F. M., MeEsters J. K., 2007. Desmids of the Lowlands. Mesotaeniaceae and Desmidiaceae of the European Lowlands. KNNV Publishing, Zeist., the Netherlands.

EICHLER B. 1890. Spis desmidyj zebranych $w$ okolicyach Międzyrzeca. Pamiętn. Fizyogr. 10, 83-92.

EloRAnta P., KwandRans J., Kuesel-Feltzmann E. 2011. Rhodophyta and Phaeophyceae. Süßwasserflora von Miiteleuropa, Band 7. Gustav Fischer Verlag, Stuttgart-New York.

GUIRY M. D. GUIRY G. M., 2021. AlgaeBase. World-wide electronic publication, National University of Ireland, Galway. https://www. algaebase.org

INDEX NOMINUM ALGARUM. University Herbarium University of California, Berkeley, Complied by Paul Silva, http://ucjeps.berkeley.edu/INA. html

KADEUBOWSKA J. Z., 1972. Chlorophyta V. Coniugales. Zygnemaceae - Zrostnicowate. Flora Słodkowodna Polski 12A. Państwowe Wydawnictwo Naukowe, Kraków.

KADŁUBOWSKA J. Z., 1984. Coniugatophyceae I. Chlorophyta VIII - Süßwasserflora von Miiteleuropa. Band 16. VEB. Gustav Fischer Verlag, Jena.

KAWECKA B. 1966. Glony osiadłe na Potamageton sp. w Morskim Oku. Acta Hydrobiol. 8, 321328.

LENARCZYK J., 2014. The algal genus Pediastrum Meyen (Chlorophyta) in Poland. Institute of Botany PAS, Kraków.

MrozińSKA T. 1984. Zielenice (Chlorophyta): Edo goniowce (Oedogoniales). Flora Polski. Państwowe Wydawnictwo Naukowe, Warszawa-Kraków.

MROZIŃSKA T., 1985. Chlorophyta VI. Oedogoniophyceae: Oedogoniales. Süßwasserflora von Miiteleuropa, Band 14. Gustav Fischer Verlag, Stuttgart-New York.

MROZIŃSKA-WEEB T., 1969. Chlorophyta IV. Oedogoniales - Edogoniowe. Flora Słodkowodna Polski 11. Państwowe Wydawnictwo Naukowe, Kraków.

PLIŃSKI M., WoŁOWSKI K., 2008. Eugleniny - Euglenophyta (Euglenoids). [W:] Flora Zatoki Gdańskiej $i$ wód przyległych (Battyk Południowy). PLINSKI M. (red.). Wydawnictwa Uniwersytetu Gdańskiego, Gdańsk, 1-83.

PLIŃSKI M., WoŁOWSKI K., 2012. Haptofity, Kryptofity $i$ Chrysofity Haptophyta, Cryptophyta, Chrysophyta. [W:] Flora Zatoki Gdańskiej i wód przyległych (Bałtyk Południowy). PLINSKI M. (red.).Wydawnictwa Uniwersytetu Gdańskiego, Gdańsk, 1-146.

SiEMIŃSKA J., 1964. Chrysophyta II. Bacillariophyceae - Okrzemki. Flora Słodkowodna Polski 6. Państwowe Wydawnictwo Naukowe, Kraków-Warszawa.

SiEMIŃSKA J., 1990. Polska bibliografia fykologiczna. Bibliografie botaniczne 3. Polska Akademia Nauk, Instytut Botaniki im. Wł. Szafera, Kraków-Wrocław.

SIEMIŃSKA J., 1995. Index of latin names of bluegreen alga taxa (Cyanophyta) noted in Poland up to the year 1980. Pol. Botan. Stud., Guidebook Series 17, 3-51.

SiEMIŃSKA J., PAJAKK J., 1992. Polska bibliografia fykologiczna za lata 1981-1990. Bibliografie botaniczne 6. Polska Akademia Nauk, Instytut Botaniki im. W. Szafera, Kraków. 
SiEmińsKA J., WoŁowski K., 2003. Catalogue of Polish procaryotic and eucaryotic algae. W. Szafer Institute of Botany. Polish Academy of Sciences.

SiemińsKA J., WoŁowsKi K., 2012. Polska Bibliografia Fykologiczna za lata 1991-2000. Bibliografie botaniczne 7. Polska Akademia Nauk, Instytut Botaniki im. W. Szafera, Kraków.

SiemińsKa J., Wolowski K., PiąteK J., WoJTAl A. Z., 2008. Glony Ojcowskiego Parku Narodowego. Ojcowski Park Narodowy, Ojców.

STARMACH K., 1972. Chlorophyta III. Zielenice Nitkowate: Ulothrichales, Ulvales, Prasiolales, Sphaeropleales, Cladophorales, Chaetophorales,Trentepohliales, Siphonales, Dichotomosiphonales. Flora Słodkowodna Polski 10. Państwowe Wydawnictwo Naukowe, Kraków-Warszawa.

STARMACH K., 1974. Cryprophyceae - Kryptofity, Dinophyceae - Dinofity, Raphidiophyceae - Rafidiophyty. Flora Słodkowodna Polski 4. Państwowe Wydawnictwo Naukowe, Kraków-Warszawa.

STARMACH K., 1977. Phaeophyta - Brunatnice, Rhodophyta - Krasnorosty. Flora Stodkowodna Polski 14. Państwowe Wydawnictwo Naukowe, Kraków-Warszawa.

STARMACH K., 1980. Chrysophyta I. Chrysophyceae - Złotowiciowce (oraz Zooflagellata wolnożyjace). Flora Słodkowodna Polski 5. Państwowe Wydawnictwo Naukowe, Kraków-Warszawa.

STARMACH K., 1983. Euglenophyta - Eugleniny. Flora Słodkowodna Polski. 3. Państwowe Wydawnictwo Naukowe, Warszawa-Kraków.
STARMACH K., 1985. Chrysophyceae und Haptophyceae. Süßwasserflora von Miiteleuropa Band 1. VEB. Gustav Fischer Verlag. Stuttgart-New York.

WASYLIK K. 1957. Desmidie w zachodniej czéści Puszczy Niepołomickiej. Fragm. Florist. geobot. 3, 153-169.

WOJTAL A., Z., 2013. Species composition and distribution of diatom assembleges in spring waters from various geological formations in southern Poland. Bibliotheca Diatomologica V. 59, 1-436.

WoŁOWSKI K., 1998. Taxonomic and environmental studies on Euglenophytes of the KrakowCzestochowa Upland (Southern Poland). Fragm. Flor. Geobot., Suppl. 6, 1-192.

WoŁowski K., 2002. Phylum Euglenophyta. [W:] Freshwater Algal Flora of the British Isles. JOHN D. M., WhiTTON B. A., BROOK A. J. (red.). Cambridge University Press, Cambridge, 144-179.

WoŁOWSKI K., 2011. Phylum Euglenophyta (Euglenoids). [W:] Freshwater Algal Flora of the British Isles. JOHN D. M., WhitTon B. A., BROOK A. J. (red.). Cambridge University Press, Cambridge, 181-239.

WoŁowski K., HindaK F., 2005. Atlas of Euglenophytes. VEDA, Bratislava.

WoŁowski K., Siemińska J., Piątek J., 2010. Polish Studies on algae of Latin America. [W:] The Nature and Culture of Latin America. MIREK Z., FlakUs A., KrZanowski A., PaUlo A., WOJTUSIAK J. (red.). Review of Polish studies W. Szafer Institute of Botany, PAS, Krakow, 189-196.

KOSMOS Vol. 70, 2, 173-181, 2021

KonRad WoŁowski, Maria Janicka, Lucyna Śliwa

Instytut Botaniki im. W. Szafera PAN, 46 Lubicz Str., 31-512 Kraków, E-mail: k.wolowski@botany.pl

FILES OF POLISH SITES OF ALGAE IN THE SCIENTIFIC COLLECTIONS OF THE W. SZAFER INSTITUTE, POLISH ACADEMY OF SCIENCES

\section{Summary}

The herbarium collections of the W. Szafer Institute of Botany of the Polish Academy of Sciences, numbering nearly 1.5 million inventoried items, are one of the main national collections and are of international importance. The collections cover not only all modern groups of plants and fungi, including one of the world's three largest algae iconothecas, but also collections of fossil floras and reference specimens for palaeobiological research. The Institute's collections are on the Polish Map of Research Infrastructure, labelled as the National Biodiversity Collection of Recent and Fossil Organisms IB PAS (NKB IB PAS). From among the seven IB PAS collections, a part of the phycological collections was selected for inclusion in the EU IMBIO project. The phycological collection currently consists of classical herbaria (about 5000 inventoried items), collections of algal cultures, the iconotheca of algae (415,510 sheets) and 28,000 files of algae sites from Poland. The files currently have about 25,000 files of algae localities, 1,681 files of cyanobacteria sites, and 1,422 files of bacteria sites. Each file in the collection gives the Latin name of the taxa, sites reported from Poland, and the number of the publication containing the information (according to published phycological bibliographies). The files, together with the phycological bibliography catalogue, have enabled the creation and publication of successive lists of names of algae given from Poland. Currently, the same resources are used to update these lists and to propose the first (also digitized) list of Polish algae under the IMBIO project. 